Jayathilake H. A. C. K., Jayasinghe-Mudalige U. K., Perera L. D. R. D., Gow G. A.

Waidyanatha N., Wayamba Journal of Management 8 (1)

\title{
Exploratory Analysis on the Management of Agricultural Knowledge and Information by Smallholder Farmers in Batticaloa District
}

\author{
H. A. C. K. Jayathilake ${ }^{1}$, U. K. Jayasinghe-Mudalige ${ }^{2}$, \\ L. D. R. D. Perera $^{3}$, G. A. Gow ${ }^{4} \&$ N. Waidyanatha ${ }^{5}$ \\ ${ }^{1}$ ICT Center, Wayamba University of Sri Lanka, Makandura, Gonawila, Sri Lanka \\ ${ }^{2}$ Department of Agribusiness Management \\ Faculty of Agriculture and Plantation Management \\ Wayamba University of Sri Lanka, Makandura, Gonawila, Sri Lanka \\ ${ }^{3}$ Department of Computing and Information Systems, Faculty of Applied Sciences \\ Wayamba University of Sri Lanka, Kuliyapitiya, Sri Lanka \\ ${ }^{4}$ Faculty of Extension, University of Alberta, Edmonton, Canada \\ ${ }^{5}$ LIRNEasia, Colombo 8, Sri Lanka \\ cjayathilake@wyb.ac.lk ${ }^{1}$
}

\begin{abstract}
Extent of farmer knowledge and availability of reliable information at the level of farm are considered key driving forces in agricultural development as both support interchangeably to transform the livelihoods of rural poor into one with increased household income stability and food security. The farmers who do not have a free/subsidized and open/fair access to the vital agricultural information would, therefore, face severe difficulties in their attempt to achieve the goals of farming. The purpose of the study was to investigate the factors that trigger or hinder farmer access to agricultural knowledge and information. The smallholder agricultural farmers in the Batticaloa district in Sri Lanka was used as the case. A series of pre-tested structured questionnaire-based face-to-face interviews were carried out with a cross section of farmers $(n=144)$ to gather data and both descriptive and quantitative techniques, including Factor and Logistics Regression analysis, were employed to analyse data. The results show that the level of acquisition of agricultural knowledge by farmers has a positive and negative relationship with the level of education and age of farmer, respectively. Amongst other factors, the farmers, in general, requested badly the valid and reliable agricultural information on a regular basis with regard to the market prices of inputs and outputs, credits/subsidies/loans etc. available and the measures of crop protection, i.e. pests and disease control. The inadequacy in information services and agricultural officers, limited infrastructure and insufficient funds/resources hinder farmer access to agricultural knowledge and information. The outcome of analysis, overall, implies the importance of developing appropriate
\end{abstract}


packages to facilitate information sharing and knowledge mobilization and targeting so to specific farming communities in need with a right mix of market-based and regulatory incentives.

Keywords: Agricultural knowledge, Information management, Smallholder farmers

\section{INTRODUCTION}

Knowledge is vital in farm development, especially in rural geographies. Access to 'agricultural knowledge' is key to transforming the livelihoods of rural poor into one with increased income stability and food security (Lwoga et al., 2010). Knowledge is filtered from information, or in other words, information is connected to knowledge through the datainformation-knowledge hierarchy (Frické, 2009).

Access to agricultural knowledge is vital for acquiring the skills and techniques required to improve farming practices, sustaining the environment and to optimize the agricultural production. The same is also influenced by the infrastructure needed for dissemination of information, which, however, is not uniformly distributed within and between countries (Mtega et al., 2016). Also, the information needs and information seeking patterns of farmers are location specific (Lwoga et al., 2011).

To address the issue on access to agriculture knowledge, therefore, a strong link between agricultural research and farmers should be established. According to Nazari et al. (2011), the agricultural research institutions should come up with new technologies and developments, and further, care must be taken to assure that those reach the farmers in need through effective extension and mass media channels.

Conversely, if agricultural technologies and developments do not reach farmers adequately, the process of transforming agriculture and farmer livelihood development would remain impossible. All these suggest that access to agricultural knowledge through valid and reliable information can be considered key for a positive change and systematic progress in the agricultural sector (Mtega et al., 2016).

The major constraints for farmers' access to agricultural information in Nigeria, according to Galadima (2014), include irrelevant information, delay in information delivery, extension workers' personalities, language barriers, and lack of feedback mechanisms. According to Mtega et al. (2016), the limited number of demonstration plots, late delivery of information services, limited number of agricultural extension agents, crop market information and poor information and communication technologies (ICTs) hindered access to agricultural knowledge among rice farmers in Tanzania.

Crowder and Fortier (2000) showed that the shortcomings of traditional print and library-based methods of providing agricultural information to rural farmers who are generally 
illiterate and relatively remote from formal sources of information and not proximity to market limit the access to agricultural knowledge.

Aina (2007) suggested that farmers could benefit from global information if information centres (i.e. Telecentres) that were equipped with all information and communication gadgets were available in rural areas to improve access to agricultural information. All these experiences in the developing nations highlight that more emphasis needs to be given to access to knowledge when formulating the policies on the development and dissemination of agricultural knowledge.

There is an abundance of knowledge on agriculture in Sri Lanka that has been generated through various sources and institutions (e.g. universities, research stations and departments). Further, those are in very different forms, e.g. printed matter, recorded and/or in cyberspace, or in the form of day-to-day communications on prevailing 'market prices' and 'weather conditions' to reviews and reports released periodically (e.g. weekly, quarterly).

Nevertheless, it is a well-known fact that the smallholder agricultural communities in the country, especially in less-developed rural areas, have persistently suffered from those issues related to receipt of appropriate knowledge and information pertaining to agriculture (information on prices and consumer demand) on time and on regular basis. This has mostly been due to the inefficiencies associated with the mode of dissemination (De
Silva and Ratnadiwakara, 2008; Jayathilake et al., 2015).

At the level of farm, the most farmers have inadequate access to and usage of the most important agricultural information needed for sustainable production (Lwoga et al., 2011). This will eventually lead to dismal growth of the agricultural sector and prevalence of poverty among households whose livelihoods rely solely on agriculture, and this also is a common phenomenon with Sri Lankan smallholder agriculture.

No need to justify that if the agricultural technologies and developments do not reach farmers in its best form and through the most economical route, transforming sustainable agriculture into productive systems, and in turn, conversion of the livelihood of poor farming households into a rich would become an unrealizable effort.

In light of these, the purpose of the study was to investigate the factors that trigger or hinder farmer access to agricultural knowledge and information. The smallholder agricultural farmers in the Batticaloa district in Sri Lanka was of special interest. The study is considered part of a comprehensive project that gathered data from eight communities identified for the Canada-Sri Lanka Partnership Development Project funded by the Social Sciences and Humanities Research Council of Canada with the view of assessing the use of low-cost communication technologies for knowledge mobilization in agricultural communities in Sri Lanka and to recommend how ICT tools could be 
used in agricultural knowledge sharing in the rural farming communities.

\section{METHODOLOGY}

Based on the literature referring to the previous studies on this area, the following conceptual framework was constructed that depicts the relationship between a number of factors that govern farmer access to agricultural information, including their demographic and perceptions, market information and accessibility and also the information repository issues (Figure 01).

Based on this framework we may hypothesize that 'a farmer access to agricultural knowledge through valid and reliable information at the right time on regular basis' is significantly associated with his/her: $\left(\mathrm{H}_{1}\right)$ age; $\left(\mathrm{H}_{2}\right)$ household income; $\left(\mathrm{H}_{3}\right)$ perception of farming as a profession; $\left(\mathrm{H}_{4}\right)$ farming experience; $\left(\mathrm{H}_{5}\right)$ price information; $\left(\mathrm{H}_{6}\right)$ market accessibility; $\left(\mathrm{H}_{7}\right)$ : sources of information services, and $\left(\mathrm{H}_{8}\right)$ access to agricultural services, including extension and officers

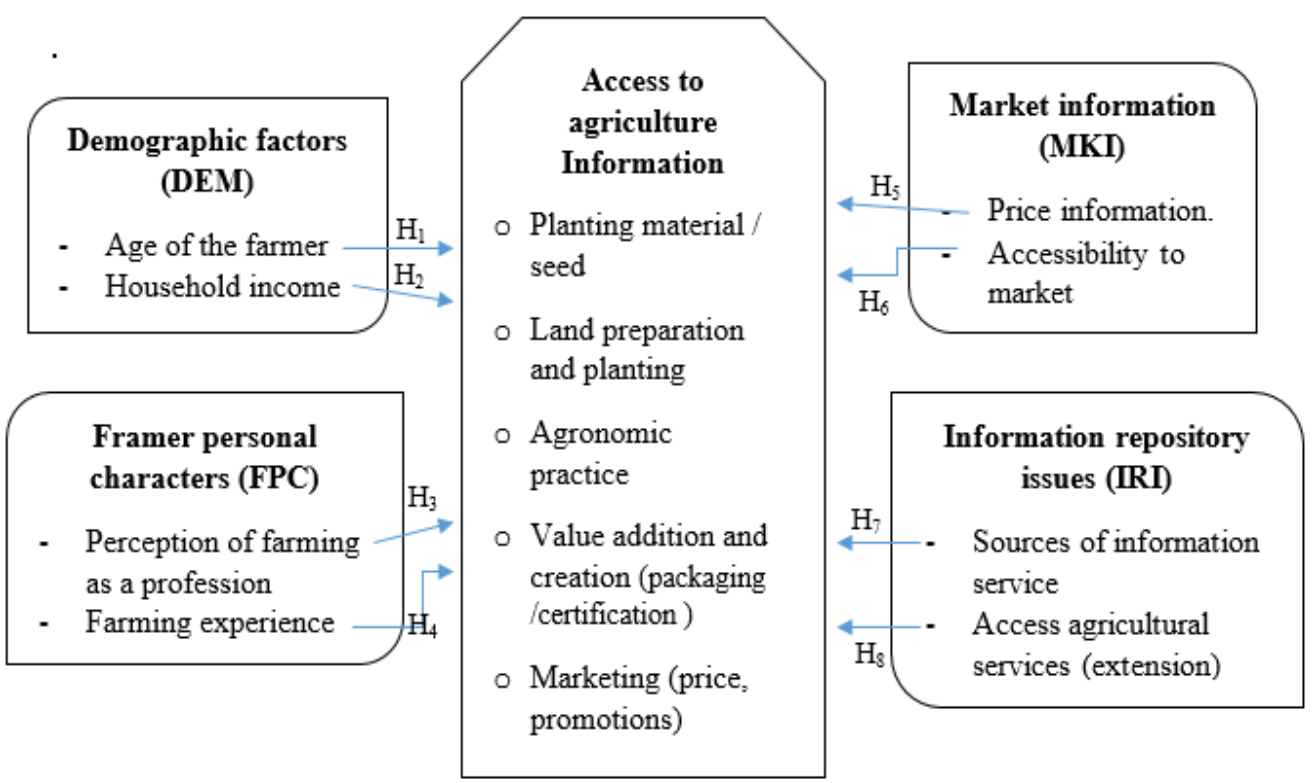

Figure 1. Conceptual Framework

\section{Study Area and Data}

The data for this particular study were gathered from agricultural communities involved with "vegetable farming" under the guidance of the Janathakshan, a nongovernmental organization operate in the Batticoloa district. It works 
extensively in the geographical areas of Vaharai and Kathiraveli Grama Niladhari (GN) Divisions in Koralai Pattu North Divisional Secretariat (DS) and Kirankulam North GN division of the Munmunai Pattu DS Division.

A series of structured face to face interview based questionnaire was carried out with a cross section of smallholder agriculture farmers ( $n$ $=144$ ) to collect the primary data. The purposive sampling technique was used in selecting farmers and the 'LIRNEasia Teleuse@BOP4' (LIRNEasia, 2012) instrument was adopted in particular for the purpose of preparation of the questionnaire to gather information pertaining to the agricultural knowledge needs (agriculture information seeking); major sources of agricultural knowledge; constraints on access to agricultural knowledge and socioeconomic and demographic data of the respondents in the study area.

Responses to most of the questions were obtained by way of a five-point likert-scale ranging from ' 1 ' (Strongly Disagree) to '5' (Strongly Agree).

The validity and reliability of the data collected for the purpose were evaluated through Cronbach's alpha value, where the alpha closer to 1.0 indicates a "better", and in general, the values less than 0.6 indicates that reliability is "poor". Commonly, the values in 0.70 range is considered "acceptable" and those over 0.80 considered "good" (Sekaran, 2006).

Prior to the extraction of the factors, Keiser-Meyer-Olking test (KMO) was used to assess the sampling adequacy and Barlett's Test of Sphericity used to assess factorability of the data. The $\mathrm{KMO}$ index ranges from 0 to 1 , with 0.5 suggested as the minimum value for a good analysis. The Barlett's Test of Sphericity should therefore be significant $(\mathrm{P}<0.05)$ for an analysis to be considered appropriate (Tobias, $\&$ Carlson, 1969).

\section{RESULTS AND DISCUSSION}

\section{Descriptive Statistics of Smallholder Farmers}

All the smallholders farmers surveyed $(n=144)$ were 'Tamils' by nationality, and a vast majority of them were 'Hindus' by religion followed by the 'Catholics' (Table 01).

The results obtained through statistical analyses were taken together with qualitative information obtained through a series of focus group discussions and on-farm/household personal observation.

Nearly 56 percent of farmers were females and the mean age of a farmer was 47 years. In fact, 52 percent of farmers in the sample were fallen within the age of 45 to 75 years. About 61 percent of farmers were classified under the income category of the lowest annual income, i.e. less than Rs. 180,000 per annum.In terms of the educational qualifications of farmers participated to the survey, 51 percent had attained up to the secondary level followed by 22 percent up to the primary level. In fact, another 7 percent had not attained any formal education; however, this particular set of farmers have also been literate enough to communicate with others in the community verbally. 
Needs, Acquisition and Usage of Knowledge and Information

Kamba (2009) stated that any community of people, including those in agriculture, is not in position to develop themselves overtime without acquiring a sufficient amount of knowledge, and the information plays a vital role in this respect by working as a vehicle of transforming and accumulating the knowledge.

Table 1. Distribution of demographic data and use of agricultural knowledge

\begin{tabular}{cccc}
\hline Variable & Category & Percentage & $\begin{array}{c}\text { Percentage Use of } \\
\text { Agricultural } \\
\text { Knowledge / } \\
\text { Information }\end{array}$ \\
\hline Sex & Female & 56 & 96 \\
Male & 44 & 94 \\
\hline Age (Years) & $20-29$ & 17 & 100 \\
& $30-44$ & 25 & 97 \\
& $45-59$ & 35 & 96 \\
& $60-74$ & 17 & 94 \\
Education & $>74$ & 6 & 80 \\
& Literate but no & 7 & 60 \\
& schooling & 22 & 93 \\
& Grade $0-5$ & 51 & 99 \\
Grade 6 -11 & 20 & 100 \\
\hline Annual & Advanced Level and & & 96 \\
household & above & 61 & 98 \\
income & Rs. 180,000 - 360,000 & 32 & 100 \\
\hline & $>$ Rs. 360,000 & 7 &
\end{tabular}

To explore the validity of this fact, the respondents were inquired in particularly about the necessity and level of utilization of agricultural knowledge and information on their long-term and day-to-day agricultural operations. It has been found that more than 95 percent of smallholding farmers badly needed, and also use heavily, the agricultural knowledge and information in this respect (see, Table 01).

Adeogun et al. (2010) stated that the younger farmers, as compared to their counterpart, i.e. older farmers, are more likely to spend their time to access into new information on improved technologies. This fact has also been proved as it was found that those "young" farmers (i.e. age 20-29 
years) in the sample and those fall into the category of the "most" educated (i.e. >Advanced Level) has requested for and use agricultural information and the knowledge more than others in their farming activities, or in other words, the demand for knowledge in agriculture and valid and reliable information has slightly been decreased as the farmers become "old" and "less educated".

Each farmer interviewed was asked to indicate the type of agriculture-related knowledge and information that they "need", and the amount that they "acquired" in reality. A list of factors were produced for them work on this, including: agricultural support programs (credit / subsidy / loan) (ASL); sustainable agronomic practices (SAP); land preparation (LDP); pest \& disease control (PDC); seed / variety selection (SVS); postharvest handling $(\mathrm{PHH})$; fertilizer application (FTA), and crop market price (CMP). The summary of outcome is depicted in Figure 02.

It shows that farmers were more concerned about the accurate and timely information about the market prices of the crops they cultivated
$(\mathrm{CMP}=96 \%), \quad$ agricultural subsidies/loan schemes (ASL $=95 \%$ ), the methods that can use to control pests and diseases $(\mathrm{PDC}=92 \%)$, and the recommendations and application of fertilizer (FTA $=85 \%$ ). Further, the gap between information need and receipt was highest in market prices of crops (CMP), agricultural support programs (ASL), and sustainable agronomic practices (SAP) suggesting that the farmers, in general, have been experiencing an inadequate access to the most important agricultural information over time.

\section{Sources of Information in Use to} Gain Agricultural Knowledge

Another important aspect considered in the analysis was the major sources of agricultural information use by the farmers. To reveal this phenomenon, a number of such sources were considered, including from the government officers (extension officers and regional development officers), farmer organizations / society, market vendors, family members, fellow farmers, library / information centre, and ICT related devices (Figure 03). 
Jayathilake H. A. C. K., Jayasinghe-Mudalige U. K., Perera L. D. R. D., Gow G. A.

Waidyanatha N., Wayamba Journal of Management 8 (1)

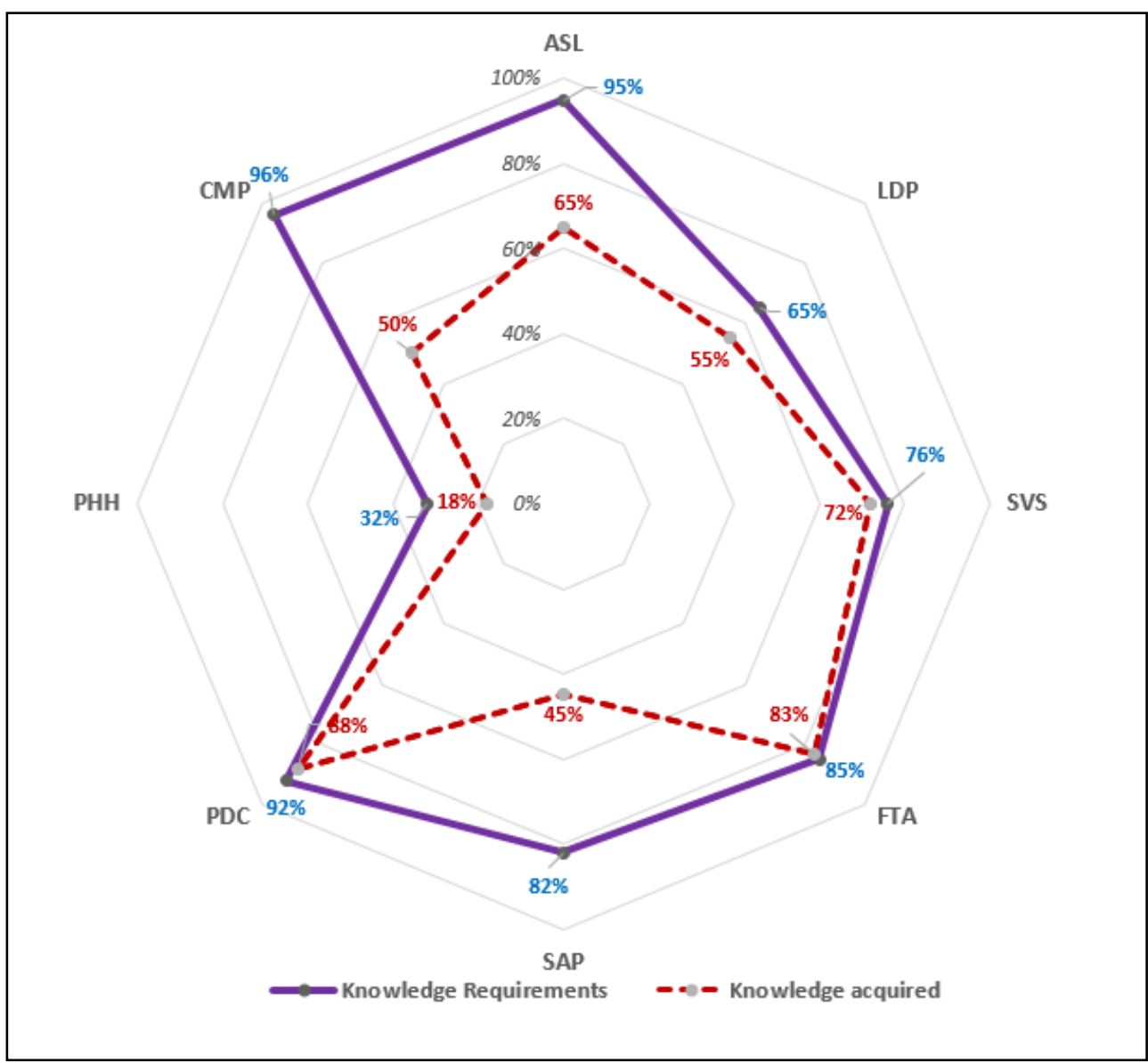

Figure 2. Type of agriculture related information expected and acquired by the surveyed communities.

Where,

ASL - agricultural subsidy/loan

LDP - land preparation

SVS - seed / variety selection

FTA - fertilizer application

The results show that the most popular sources of information include the government officers $(81 \%)$, followed by the farmer organizations $(65 \%)$ and
SAP - sustainable agronomic practices PDC - pest \& disease control $\mathrm{PHH}$ - post harvest handling CMP - crop market price

market vendors (60\%). The least popular ways and means include the ICT devices (18\%) and library / information centres (8\%) (Figure 03). 
Jayathilake H. A. C. K., Jayasinghe-Mudalige U. K., Perera L. D. R. D., Gow G. A.

Waidyanatha N., Wayamba Journal of Management 8 (1)

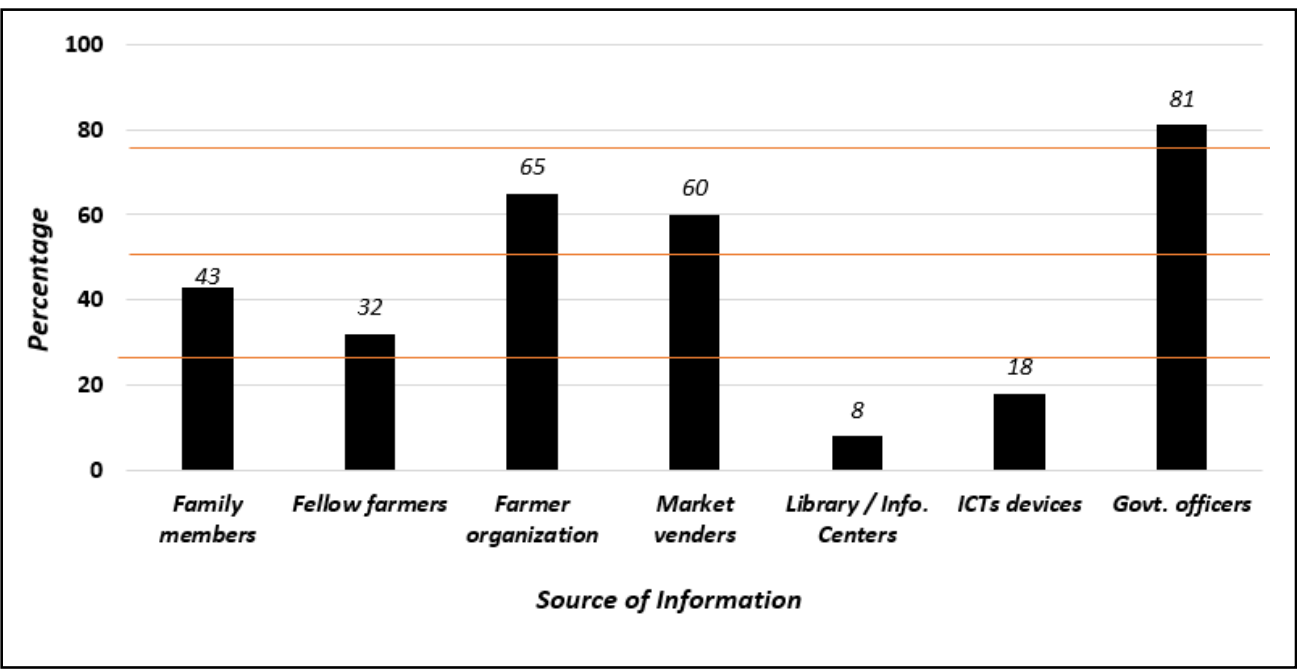

Figure 3. Different sources of agriculture information seeking by the farmers

$$
(n=144)
$$

Further, they were asked to indicate the use of ICT-related devices, for example television, radio, telephone (mobile / fixed), computer and internet in their daily lives for communication. It has been found that more than 82 percent of farmers in the community use at least one of some model of phone to take or receive a telephone call in the recent past, and nearly 58 percent use their own mobile phone/s for this purpose (Figure 04).

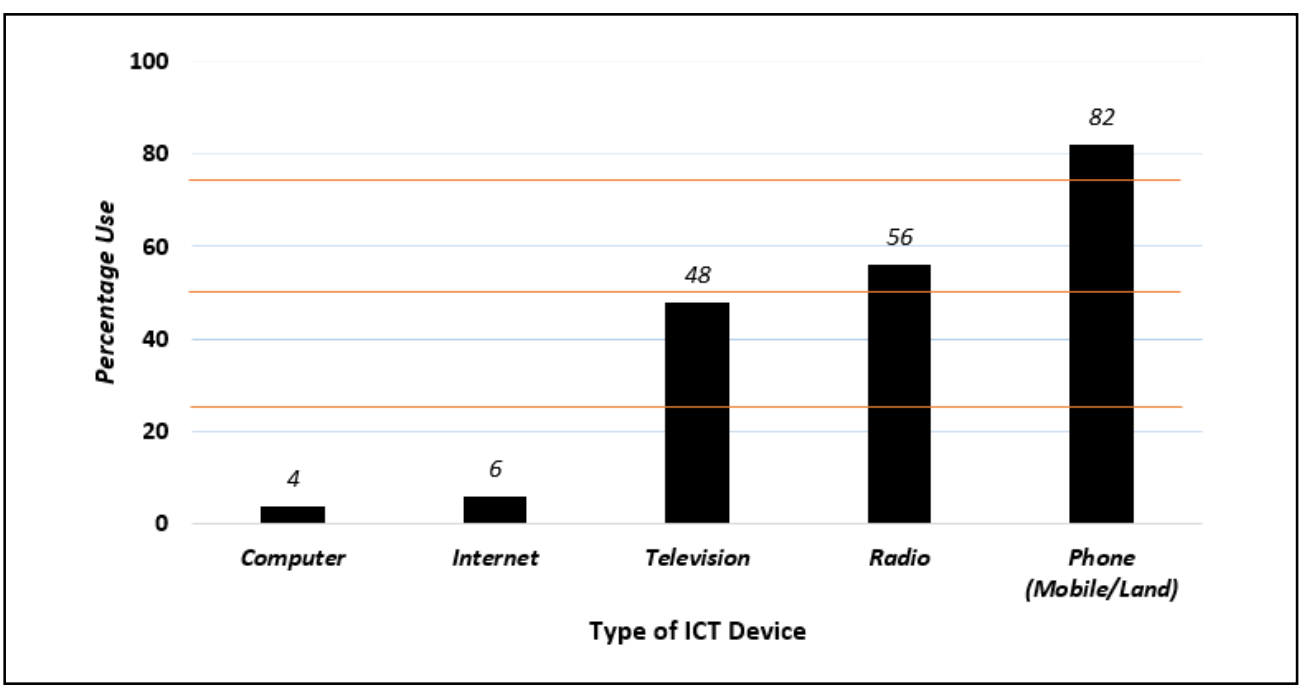

Figure 4. Farmers ICT devices usage in day-to-day communication

In fact, more than 76 percent of farmers in the sample use a mobile phone to take and/or receive phone calls "regularly" for various purposes. 
However, only about 16 percent of farmers were familiar with and/or use the SMS facility on the phone for the purpose of communication with third parties. This suggests that there exists a great opportunity to promote the mobile phones possess by farmers to break the existing gaps in access to agricultural knowledge and information.

The respondents were asked to indicate the factors that limit their access to agricultural information. The eight key aspects included in the conceptual framework were selected specifically for this purpose.

These were subjected to a number of statistical analysis to verify their validity and reliability. It was found that Cronbach's alpha value of all factors (Scale reliability coefficient $=$ 0.687), except the perception of farming as a career, resulted more than 0.60. The adequacy of the sample was measured using KMO and Barlett's test of sphericity. The KMO value was 0.672 , which is greater than the rule of thumb 0.50, and Barlett's test of sphericity aslo indicate the significant $(\mathrm{P}=0.001)$.

The results show that the lack of information services (93\%), lack of agricultural officers, i.e. extension officer and regional development officer (87\%), farmers age (80\%), price information (price of seed, planting material, fertilizer, pesticide, market price etc. $(76 \%)$, and market accessibility (58\%) were the key constraints faced by farmers, in general (Table 02).

A Logistic regression model was employed to see the relationship between those constraints considered in Table 02 and the farmers' access to agricultural knowledge and information.

The model was significant and the Likelihood Ratio Chi-square of 49.86 with a p-value of 0.0001 . Out of the eight hypotheses specified to reflect those factors in conceptual framework, the hypotheses of $\mathrm{H}_{1}, \mathrm{H}_{4}$, $\mathrm{H}_{5}, \mathrm{H}_{6}, \mathrm{H}_{7}$ and $\mathrm{H}_{8}$ are statistically significant, while $\mathrm{H}_{2}$ and $\mathrm{H}_{3}$ are not statistically significant. The results, overall, implies that farmer's level of age, poor information services in the area, availability of agricultural officers, farmer experience, price information and market accessibility possess a significant effect on the farmers access to agricultural knowledge and information.

Table 2. Summery statistics of the factors limits the access to agricultural information

\begin{tabular}{|c|c|c|c|c|c|c|c|}
\hline \multirow[t]{2}{*}{ Category } & \multirow[t]{2}{*}{ Factors } & \multicolumn{3}{|c|}{ Percentage } & \multirow{2}{*}{$\begin{array}{l}\text { Cronbach's } \\
\text { Alpha value }\end{array}$} & \multirow[t]{2}{*}{$\mathbf{z}$} & \multirow[t]{2}{*}{$\mathbf{P}>|\mathbf{z}|$} \\
\hline & & $\frac{0}{\sum^{5}}$ & & है & & & \\
\hline \multirow[t]{2}{*}{ DEM } & Age of the farmer & 76 & 84 & 80 & 0.825 & $2.43 *$ & 0.021 \\
\hline & Household income & 48 & 40 & 43 & 0.524 & 4.21 & 0.064 \\
\hline
\end{tabular}




\begin{tabular}{|c|c|c|c|c|c|c|c|}
\hline \multirow[t]{2}{*}{ FPC } & $\begin{array}{l}\text { Perception of } \\
\text { farming as a career }\end{array}$ & 32 & 26 & 28 & 0.312 & 4.41 & 0.072 \\
\hline & Farming experience & 76 & 52 & 63 & 0.741 & $2.95^{*}$ & 0.036 \\
\hline \multirow[t]{2}{*}{ MKI } & Price information & 76 & 76 & 76 & 0.725 & $3.13^{*}$ & 0.047 \\
\hline & $\begin{array}{l}\text { Accessibility to } \\
\text { market }\end{array}$ & 73 & 55 & 70 & 0.611 & $2.78^{*}$ & 0.034 \\
\hline \multirow[t]{2}{*}{ IRI } & $\begin{array}{l}\text { Sources of } \\
\text { information service }\end{array}$ & 89 & 96 & 93 & 0.893 & $2.55^{*}$ & 0.027 \\
\hline & $\begin{array}{l}\text { Access agricultural } \\
\text { services (extension) }\end{array}$ & 82 & 90 & 87 & 0.861 & $2.61 *$ & 0.029 \\
\hline
\end{tabular}

\section{CONCLUSIONS}

The findings of study show that almost ninety five percent of vegetable farmers in batticola have an access and utilize agricultural knowledge and information in their farming related activities. Amongst the other factors, those farmers, in general, need badly the valid and reliable agricultural information on a regular basis with regard to the market prices of inputs and outputs, credits / subsidies / loans etc. available and the measures of crop protection, i.e. pests and disease control.

The inadequacy in information services and agricultural officers, limited infrastructure and insufficient funds / resources hinder effective farmer access to agricultural knowledge and information.

In light of these, it is of utmost importance that information providers, both private and public, identify all these challenges, and in turn, provide farmers with a convenient and economical access to valid and reliable agricultural knowledge and information. It is really important that the information needed by rural farmers are repackaged in a language they can understand and offer to them at the appropriate time.

There is a need for government and other responsible institutions to lay more emphasis on sustainable practices for information accessibility to smallholder farmers and also to disseminate information to them and address their information needs properly.

From policy point of view, the outcome of analysis, overall, highlight the importance of developing appropriate packages to facilitate information sharing and knowledge mobilization and targeting so to specific farming communities in need with a right mix of market-based and regulatory incentives.

\section{Acknowledgement}

This project is made possible through the funding from the Social Sciences and Humanities Research Council (SSHRC) of Canada and the Competitive Research Grants Scheme of the Wayamba University of Sri Lanka (SRHDC/RP/04/13-05). 


\section{REFERENCES}

Adeogun, S.O., Olawoye, J.E. and Akinbile, L.A. (2010). Information sources to cocoa farmers on cocoa rehabilitation techniques (CRTs) in selected states of Nigeria, Journal Media and communication studies. 2(1): $9-15$.

Aina, L. O. (2007). Globalisation and small-scale farming in Africa: what role for information centres. In World Library and Information congress: 73rd IFLA general conference and council. 1-8pp.

Crowder, L. V., and Fortier, F. (2000). National Agricultural and Rural Knowledge and Information Systems (NARKIS): A Proposed Component of the Uganda National Agricultural Advisory Service (NAADS). FAO, Rome. 22pp.

De Silva, H., and Ratnadiwakara, D. (2008). Using ICT to reduce transaction costs in agriculture through better communication: A case-study from Sri Lanka. LIRNEasia, Colombo, Sri Lanka, Nov.

http://www.lirneasia.net/wpcontent/uploads/2008/11/transact ioncosts.pdf. 15.03.2015

Frické, M. (2009). The knowledge pyramid: A critique of the DIKW hierarchy, Journal of Information Science. 35(2): 131-142.

Galadima, M. (2014). Constraints on Farmers Access to Agricultural Information Delivery: A Survey of Rural Farmers in Yobe state, Nigeria. IOSRJAVS IOSR Journal of Agriculture and Veterinary Science, 7(9), 18-22.

Jayathilake, H.A.C.K., JayasingheMudalige, U.K., Gow, G.A., Waidyanatha, N. and Perera, L.D.R.D. (2015). Use of Low Cost Information Communication Technologies for Knowledge Mobilization in Agricultural Communities in Sri Lanka. $8^{\text {th }}$ International Research Conference, General Sir John Kothalawala Defence University, Rathmalana, Sri Lanka. 85pp.

Kamba, A.K. (2009). Access to information: The dilemma for rural community development in Africa.

http://globelics2009dakar.merit.u nu.edu/papers/1238296264_MA. pdf. 15.02.2016.

LIRNEasia, (2012). Teleuse at the Bottom of the Pyramid 4 (Teleuse@BOP4).

http://lirneasia.net/projects/201012-researchprogram/teleusebop4. 15.10.2015.

Lwoga, E. T., Ngulube, P., and Stilwell, C. (2010). The management of indigenous knowledge with other knowledge systems for agricultural development: challenges and opportunities for developing countries. In Scientific and Technical Information and Rural Development IAALD XIIIth World Congress. 26-29.

Lwoga, E. T., Stilwell, C. and Ngulube, P. (2011). Access and use of agricultural information 
and knowledge in Tanzania, Library Review. 60(5): 383-395.

Mtega, W. P., Ngoepe, M., and Dube, L. (2016). Factors influencing access to agricultural knowledge: the case of smallholder rice farmers in the Kilombero district of Tanzania: original research, South African Journal of Information Management. 18(1): $1-8$.

Nazari, M.R., Bin, H.J. \& Hassan, S. (2011). The role of television in the enhancement of farmers agricultural knowledge, African Journal of Agricultural Research. 6(4): 931-936.
Sekaran, U. (2006). Research methods for business: A skill building approach. John Wiley \& Sons.

Tobias, S., \& Carlson, J. E. (1969). Brief report: Bartlett's test of sphericity and chance findings in factor analysis. Multivariate Behavioral Research, 4(3), 375377 